\title{
LRRN2 wt Allele
}

National Cancer Institute

\section{Source}

National Cancer Institute. LRRN2 wt Allele. NCI Thesaurus. Code C54258.

Human LRRN2 wild-type allele is located in the vicinity of $1 \mathrm{q} 32.1$ and is approximately 69 $\mathrm{kb}$ in length. This allele, which encodes leucine rich repeat neuronal protein 2 , may be involved in both cellular adhesion and ligand recognition. The wild-type allele is aberrantly expressed in malignant gliomas. 